Proc. Estonian Acad. Sci. Eng., 2003, 9, 4, 281-292

\title{
Determination of residual stresses in a galvanic coating
}

\author{
Alexander Ryabchikov, Harri Lille, and Jakub Kõo \\ Chair of Structural Mechanics and Engineering, Estonian Agricultural University, Kreutzwaldi 5, \\ 51014 Tartu, Estonia; alexrj@eau.ee
}

Received 7 July 2003, in revised form 21 October 2003

\begin{abstract}
A method for the determination of residual stresses in a galvanic coating by measuring the longitudinal deformation of a straight strip (ribbon) substrate was elaborated. For this purpose, an experimental measuring system was designed. Experiments were carried out using a nickel coating deposited bilaterally from Watt's electrolyte on a copper or brass strip substrate, and residual stresses were calculated. An equipment for fixing the strip substrate at one end and a load with a calibrated weight at the other was designed. The longitudinal displacement of the free end of the substrate, depending on the coating thickness, was determined by measuring the deformation of the elastic element. The effect of the rigidity of the elastic element on residual stresses was investigated. The results are compared with the literature data.
\end{abstract}

Key words: residual stress, strip substrate, elastic element, longitudinal deformation, galvanic coating, measuring system.

\section{INTRODUCTION}

Electrodeposition is the most convenient method for applying ordinary metal coatings of a high melting point such as chromium, nickel, copper, and silver. Application of galvanic coatings for decorative purposes and for corrosion resistance is the most common use of electrodeposition. The laying of coatings is accompanied by residual stresses. Critical residual stresses can cause harmful effects as cracking, flaking, debonding, etc. Since residual stresses cannot be calculated, numerous experimental methods have been worked out for this purpose.

One of the methods for the determination of residual stresses in the coating, used in laboratory and factory conditions, is measurement of the longitudinal deformation of a straight strip (ribbon) substrate $\left[{ }^{1-7}\right]$. Various experimental devices for this method have been elaborated $\left[^{2,3,8-11}\right]$. 
A well-known stress meter was invented by Dvořák and Vrobel $\left[{ }^{2}\right]$. This stress meter has been marketed under the name of EFCO Internal Stress Meter. The change of the length of a strip substrate is recorded by a deviation meter and prestressing is realized using a spring. The substrate is fixed at one end and the longitudinal displacement of its free end, depending on the coating thickness, is recorded continuously during the process of coating deposition. In order to ensure the stability of the substrate, it can be prestressed using an elastic element (spring) $\left.{ }^{2,9}\right]$ or a weight. This method is known as "dilatometric" method. Substrates used in the dilatometric method are simple (less expensive), very thin, or have a small diameter and are easily deformable.

The effect of prestressing of the substrate using an elastic element was investigated in $\left.{ }^{12}\right]$. In this study it was shown that prestressing of the substrate by a weight, unlike prestressing by an elastic element, has no effect on the value of the residual stresses.

In the present paper a strip substrate was prestressed simultaneously by an elastic element and by a calibrated weight. The initial stresses were determined in the galvanic nickel coating deposited from Watt's electrolyte on both sides of the strip substrate. When the coating is deposited on both sides of the strip, insulation is not applied and the possibility of contamination of the electrolyte is reduced.

For testing the measuring system, a nickel coating, one of the oldest protective-decorative galvanic coatings, was chosen. A nickel coating can be deposited on copper, brass, steel, and other basic metals. Data for comparison of the results of our experiments with those obtained by other researchers can be found in literature. The measuring system used for the determination of initial stresses is described and it is capable of measuring both tensile and compressive stresses with an equal accuracy. The longitudinal deformation of a strip substrate was reduced to the deflection of the middle section of the elastic element manufactured as a beam of constant stress. The deformation of the elastic element was measured during the deposition process by four foil strain gauges glued onto its outer surfaces. The deformation signals were stored in the processor of a multichannel strain indicator and were further entered in the microcomputer. This kind of measuring system allows to automate the process of obtaining experimental information and to calculate the values of initial stresses depending on the coating thickness. Note that it is possible to calculate initial stresses in the coating from the measured deformation of a specimen at any stage of electrodeposition.

In order to investigate the influence of the elastic element on the initial stresses, four elastic elements with different rigidities were designed. Five series of experiments were carried out and initial stresses were calculated assuming that the dependence of the initial stress on the coating thickness is linearfractional $\left[{ }^{13}\right]$. 


\section{DETERMINATION OF THE RESIDUAL STRESSES}

\subsection{Calculation of the residual stresses}

According to a generalized algorithm of layer growing/removing method $\left[{ }^{14}\right]$, residual stresses in a coating can be calculated as the sum of initial (superficial) and additional stresses. Consequently, it is possible to calculate additional stresses in the coating, if initial stresses are known. Additional stresses are stresses which arise in this layer when subsequent layers are applied. The coated substrate (part) is usually so rigid that residual stresses are practically equal to the initial stresses. Therefore here initial stresses are called residual stresses.

The residual stresses were calculated from the measured longitudinal deformation of a strip substrate using the generalized formula developed in $\left[{ }^{13}\right]$

$$
\bar{\sigma}(h)=-\left\{\frac{f(h)}{l_{1}}+\frac{C}{2 b}\left[\frac{2 l_{2}}{E_{1} h_{1} l_{1}} f(h)+\frac{g(h)}{e(h)}\right]\right\} \frac{\mathrm{d} w(h)}{\mathrm{d} h},
$$

where

$$
\begin{aligned}
& f(h)=\frac{E_{1}}{1-\mu_{1}} \frac{h_{1}}{2}+\frac{E_{2} h}{1-\mu_{2}}, \\
& g(h)=\frac{E_{1}}{1-\mu_{1}^{2}} \frac{h_{1}}{2}+\frac{E_{2} h}{1-\mu_{2}^{2}}, \\
& e(h)=\frac{E_{1}}{1+\mu_{1}} \frac{h_{1}}{2}+\frac{E_{2} h}{1+\mu_{2}},
\end{aligned}
$$

$E_{1}$ and $E_{2}$ are the moduli of elasticity of the substrate and coating, respectively, $\mu_{1}$ and $\mu_{2}$ are the Poisson ratios of the substrate and coating, $l_{1}$ is the length of the coating, $l_{2}$ is the length of the free substrate, $h$ is the current thickness of the coating, $h_{2}$ is the final thickness of the coating, $h_{1}$ is substrate thickness, $b$ is the width of the strip substrate, $C$ is the rigidity of the elastic element, and $w(h)$ is the longitudinal displacement of the upper end of the strip substrate.

Formula (1) was obtained assuming the plane stress state of the substrate with a coating and using the Kirhoff deformation hypothesis (deformations do not depend on the coordinate throughout the thickness). When using formula (1), it should be taken into account that differentiation between the measured experimental data $w(h)$ is sensitive to measurement errors. To obtain reliable results, special methods for numerical differentiation of experimental data or their preliminary approximation should be used.

An equation for approximation of the experimental information can be developed assuming that the dependence of the residual stress on the coating thickness is linear-fractional $\left[{ }^{13}\right]$ 


$$
\bar{\sigma}(h)=\bar{\sigma}_{0} \frac{h_{2}+h}{h_{2}+c h},
$$

where $\bar{\sigma}_{0}$ is residual stress at the beginning of deposition $(h=0)$ and $c$ is a dimensionless constant.

Taking into account Eq. (2), the following equation is obtained from (1) for the approximation of the measured displacements:

$$
w(h)=-\bar{\sigma}_{0} \int_{0}^{h} \frac{h_{2}+h}{h_{2}+c h}\left\{\frac{f(h)}{l_{1}}+\frac{C}{2 b}\left[\frac{2 l_{2}}{E_{1} h_{1} l_{1}} f(h)+\frac{g(h)}{e(h)}\right]\right\}^{-1} \mathrm{~d} h .
$$

Thus the determination of the residual stress is reduced to the finding of the constants $\bar{\sigma}_{0}$ and $c$ from Eq. (3). The constants should be determined so that the measured displacements $w(h)$ are approximated in the best way. This problem can be solved using modern programs of regression analysis. In our studies the regression function genfit ( $v x, \mathrm{v} y, F)$ of the computer program Mathcad $\left[{ }^{15}\right]$ was employed.

\subsection{Experimental system and procedure}

In this study residual stresses were determined with an experimental measuring system shown in Fig. 1. It consists of the following components: an electrolyte cell with the heating element on its bottom; an air circulation collector and an equipment for fixing the substrate and the elastic element; an air pump; a rectifier for feeding the process of electrolysis and for maintaining stable heating temperature; a strain indicator supplied with a processor for recording and storing data; a microcomputer and a printer.

Deposition takes place in the electrolytic cell with a volume of $300 \mathrm{~cm}^{3}$, covered with a lid consisting of two parts between which is placed the equipment for fixing the substrate and the elastic element. Continuous circulation of the electrolyte is guaranteed by pumping air into two air collectors located near the bottom in the opposite corners of the cell. The temperature of the electrolyte is maintained on the required level using a heating element with variable power. Two cathode nickel plates, serving as the anode, are fixed to the lid on the opposite sides of the strip substrate.

An equipment was designed for fixing the strip substrate at one end and for prestressing it by an elastic element and a calibrated weight at the other (Fig. 2). The basic material was plexiglass. Quartz tubes were used for the stands, because quartz has a very small (practically zero) coefficient of thermal expansion and allows to use various substrate materials. A supplementary screen at the side of the strip substrate was used for obtaining a uniform coating.

Longitudinal displacements, depending on the coating thickness, were reduced to the deflection of the middle cross-section of the elastic element (manufactured from spring steel) representing a beam with constant stress. The effect of the 


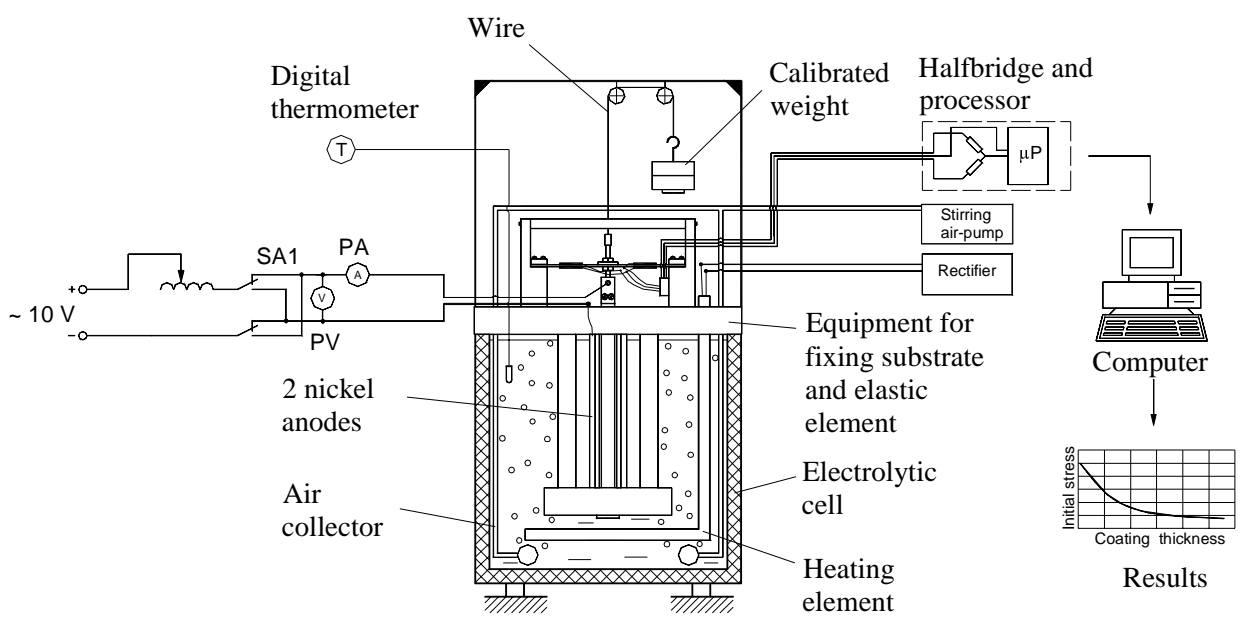

Fig. 1. Experimental system for measuring residual stress in a galvanic coating.

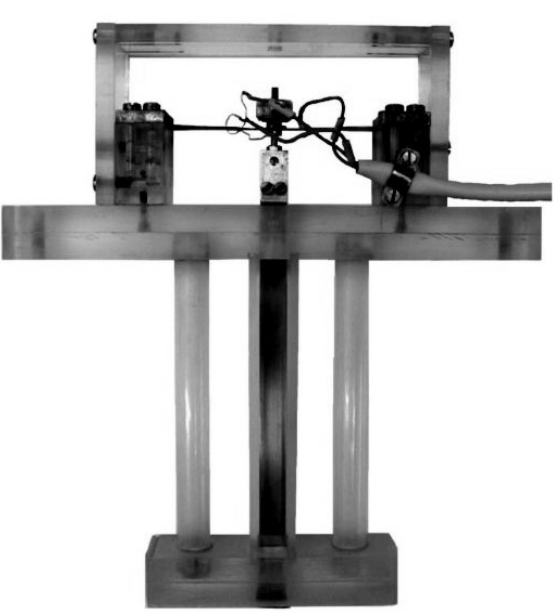

(a)

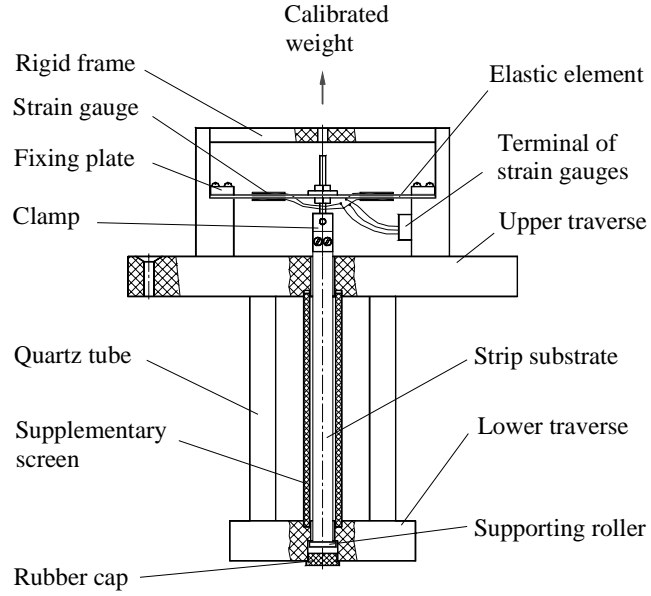

(b)

Fig. 2. Equipment for fixing the substrate and the elastic element: $a$ - overall view; $b$ - schematic.

rigidity of the elastic element on residual stresses was investigated. For this purpose four elastic elements with the following dimensions were manufactured: No. 1 - $107 \times 15 \times 0.35 \mathrm{~mm}$; No. $2-107 \times 15 \times 0.5 \mathrm{~mm}$; No. $3-107 \times 15 \times$ $0.7 \mathrm{~mm}$; No. $4-107 \times 15 \times 1 \mathrm{~mm}$. Calibration of the elastic elements represented a separate experiment. An elastic element has to be fixed to the equipment. Further it should be loaded mechanically to reproduce a deflection equal to that obtained during electrodeposition. The deflection of the middle section of the elastic element was measured with a precision of $0.002 \mathrm{~mm}$. As a 
result, the magnitude of the measuring units of the strain indicator and the stiffness coefficient were obtained (Table 1).

The strips (section dimensions $10 \times 0.13 \mathrm{~mm}$ and $10 \times 0.15 \mathrm{~mm}$, total length $152 \mathrm{~mm})$, used as the substrate, were cut off from a rolled copper $(99.9 \% \mathrm{Cu})$ or brass $(35-38 \% \mathrm{Zn}$, rest $\mathrm{Cu}$ ) ribbon. In order to attain higher sensitivity of the method, copper and brass were chosen as the materials of the substrates. A copper roller of support was soldered onto the fixed end of the substrate. Next, the substrate was prepared for deposition process. Its edges were filed and the sides were polished with sandpaper, and cleaned by acetone and viennese lime; the thickness of the substrate was measured with a precision of $\pm 0.002 \mathrm{~mm}$. The substrate was weighed on the Sartorius Balance BA61 (readability $0.0001 \mathrm{~g}$ ), placed in the equipment and chemically activated. The equipment was immersed in the electrolytic cell and fixed; a calibrated weight of $29.4 \mathrm{~N}$ was suspended from a wire. When the deformation readings had stabilized, electrodepositing process was switched on.

Table 1. Data of the substrate with coating and the results of the experiments

\begin{tabular}{|c|c|c|c|c|c|}
\hline \multirow[t]{2}{*}{ Parameter } & \multicolumn{5}{|c|}{ No of the experiment } \\
\hline & 1 & 2 & 3 & 4 & $5 *$ \\
\hline Width of substrate $b, \mathrm{~mm}$ & 9.94 & 9.91 & 9.93 & 9.92 & 9.92 \\
\hline Thickness of substrate $h_{1}, \mathrm{~mm}$ & 0.129 & 0.130 & 0.132 & 0.132 & 0.15 \\
\hline Thickness of substrate with coating, mm & 0.321 & 0.320 & 0.320 & 0.326 & 0.362 \\
\hline Length of coating $l_{1}, \mathrm{~mm}$ & 103.3 & 102.7 & 101.7 & 100.8 & 99.0 \\
\hline Length of free substrate $l_{2}, \mathrm{~mm}$ & 39.7 & 40.3 & 41.3 & 42.2 & 44.0 \\
\hline Finite coating thickness $h_{2}, \mathrm{~mm}$ & 0.096 & 0.095 & 0.094 & 0.097 & 0.106 \\
\hline Substrate prestressing $F, \mathrm{~N}$ & 29.4 & 29.4 & 29.4 & 29.4 & 29.4 \\
\hline Rigidity of the elastic element $C, \mathrm{~N} / \mathrm{mm}$ & 6.17 & 12.61 & 29.38 & 61.29 & 61.29 \\
\hline $\begin{array}{l}\text { Magnitude of the measuring units of the } \\
\text { strain indicator } \times 10^{-4}, \mathrm{~mm} \text { per unit }\end{array}$ & 5.806 & 3.718 & 3.127 & 2.610 & 2.610 \\
\hline $\begin{array}{l}\text { Contraction at finite coating thickness of } \\
\text { experimental substrate by } w\left(h_{2}\right), \mathrm{mm}\end{array}$ & 0.080 & 0.088 & 0.062 & 0.068 & 0.55 \\
\hline $\begin{array}{l}\text { Smoothed contraction of substrate at } \\
\text { finite coating thickness } w\left(h_{2}\right), \mathrm{mm}\end{array}$ & 0.080 & 0.088 & 0.063 & 0.070 & 0.055 \\
\hline Residual stress at the beginning of & 246.4 & 261.5 & 256.2 & 253.4 & 233.0 \\
\hline deposition $(h=0) \bar{\sigma}_{0}, \mathrm{~N} / \mathrm{mm}^{2} * *$ & $\overline{244.9}$ & $\overline{258.1}$ & $\overline{248.6}$ & $\overline{238.4}$ & $\overline{221.0}$ \\
\hline Dimensionless constant $c^{* *}$ & 3.08 & 2.66 & 4.94 & 3.76 & 4.73 \\
\hline & $\overline{3.07}$ & $\overline{2.64}$ & $\overline{4.86}$ & $\overline{3.63}$ & $\overline{4.60}$ \\
\hline $\begin{array}{l}\text { Difference caused by neglecting the } \\
\text { rigidity of the elastic element, } \%\end{array}$ & 0.6 & 1.3 & 3.0 & 5.9 & 5.2 \\
\hline
\end{tabular}

\footnotetext{
* Experiment No. 5 was carried out using the elastic element No. 4. The material of the substrate was brass $\left(E_{1}=115 \times 10^{3} \mathrm{~N} / \mathrm{mm}^{2}, \mu_{1}=0.34\right)$.

** The numerator gives the values if rigidity of the elastic element is taken into account and the denominator without it.
} 
The nickel coating on the part of the substrate with a length of about $101.5 \pm 1.5 \mathrm{~mm}$ was deposited from Watt's bath containing $\mathrm{Ni} \mathrm{SO}_{4} \times 7 \mathrm{H}_{2} \mathrm{O}$ $(350 \mathrm{~g} / \mathrm{l}), \mathrm{Ni} \mathrm{Cl} \mathrm{Cl}_{2} \times 6 \mathrm{H}_{2} \mathrm{O}(45 \mathrm{~g} / \mathrm{l}), \mathrm{H}_{2} \mathrm{BO}_{3}(35 \mathrm{~g} / \mathrm{l}), \mathrm{H}_{2} \mathrm{O}(570 \mathrm{~g})$ with a gravity of $1.19 \pm 0.01 \mathrm{~g} / \mathrm{cm}^{3}$ at a cathode current density of $3.95 \pm 0.05 \mathrm{~A} / \mathrm{dm}^{2}$, temperature of $55 \pm 0.1^{\circ} \mathrm{C}$, and $\mathrm{pH}=5.3-5.5$ (determined at $55^{\circ} \mathrm{C}$ ). Two cathode nickel plates with a size of $20 \times 7 \times 130 \mathrm{~mm}$ were used as the anode. They were symmetrically fixed on both sides of the substrate. Note that current density was taken the same as that used in the investigation of Hadian $\left[{ }^{16}\right]$. The largest residual stresses were obtained with the use of Watt's electrolyte when current density was $4.0 \mathrm{~A} / \mathrm{dm}^{2}$ and $\mathrm{pH}$ was $4-6\left[{ }^{16}\right]$. High bath temperature, from 50 to $55^{\circ} \mathrm{C}$, promotes crackfree coatings. The electrolyte was intensive, mixed with air during the deposition process.

Deformation was measured during the coating process using four foil strain gauges (KF5P1-15-100-B-12, base length $15 \mathrm{~mm}$, resistance $100 \Omega$, gauge factor 2.2 at $20 \pm 1{ }^{\circ} \mathrm{C}$, Co VEDA, Kiew, Ukraine) glued onto the outer surfaces of the elastic element and covered by a lacquer. The results were stored in a multichannel strain indicator supplied with a processor. The data were entered into the computer as experimental information for the calculation of residual stresses. The process lasted $126 \mathrm{~min}$ and the deformation readings were recorded with an interval of $30 \mathrm{sec}$. When the process was finished, the substrate with the coating was removed from the equipment and cleaned, dried, and weighed.

The final thickness of the substrate with the coating and the length of the deposited coating were measured. Measured coating thickness was corrected using a weight, by calculating average coating thickness from the difference in the specimen's weight before and after deposition. According to the deformation readings, coating thickness was divided into 252 equal parts; thus we had 252 pairs of readings from a single experiment. The deformation of the elastic element was converted to the longitudinal deformation of the cathode according to the calibration results and was further used as experimental information.

\section{RESULTS}

Using the computer program MS Excel and the calibration results, the experimental data were converted to the displacement of the substrate $w$ depending on the coating thickness $h$. Since all experiments were carried out under similar conditions, the data of the three experiments were pooled (Fig. 3). The measured values fluctuate to a great extent. This may be caused by the error of the strain indicator and by the slight vibration of the electrolyte cell during the measurement of deformation; however, as the values remain in a zone of a sufficiently uniform width, they can be approximated by an analytical formula.

As an example of determining the residual stress, the results of the experiment No. 3 (see Table 1) are presented for the nickel coating deposited on the copper substrate. The following values were used in the calculations: $E_{1}=110 \times 10^{3} \mathrm{~N} / \mathrm{mm}^{2}, \quad \mu_{1}=0.34, \quad E_{2}=178 \times 10^{3} \mathrm{~N} / \mathrm{mm}^{2}, \quad \mu_{2}=0.31$. The 


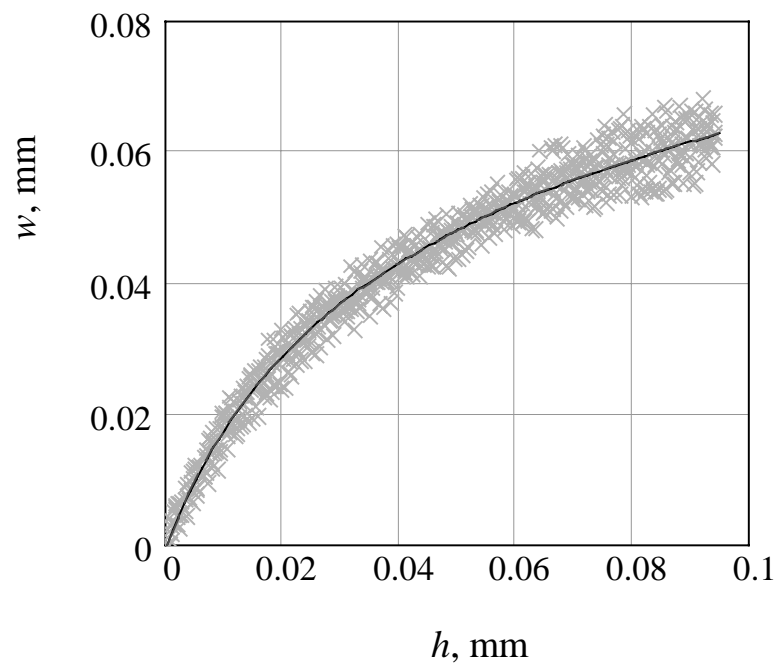

Fig. 3. Experimental values of the displacement of the upper end of the strip substrate depending on the coating thickness and the curve of approximation.

results of approximation are: $\bar{\sigma}_{0}=256.2 \mathrm{~N} / \mathrm{mm}^{2}, c=4.94$. The obtained function $w(h)$ is shown in Fig. 3. It is evident that the approximation of the experimental data using Eq. (3) is satisfactory. Figure 4 demonstrates the change of residual stresses through the coating thickness, calculated by formula (2).

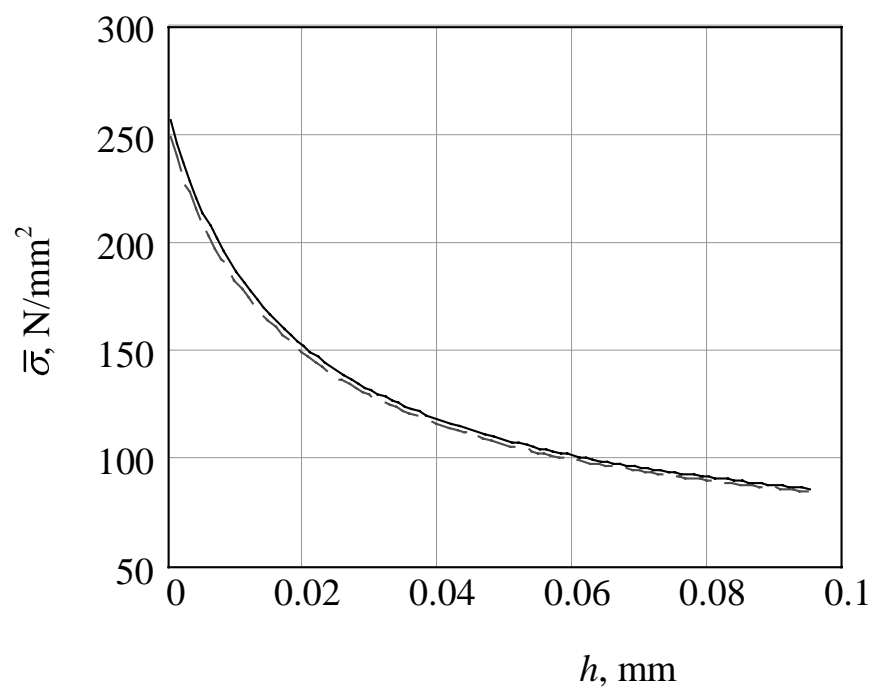

Fig. 4. Dependence of residual stresses on the coating thickness (dashed line shows the case when the rigidity of the elastic element is not taken into account). 


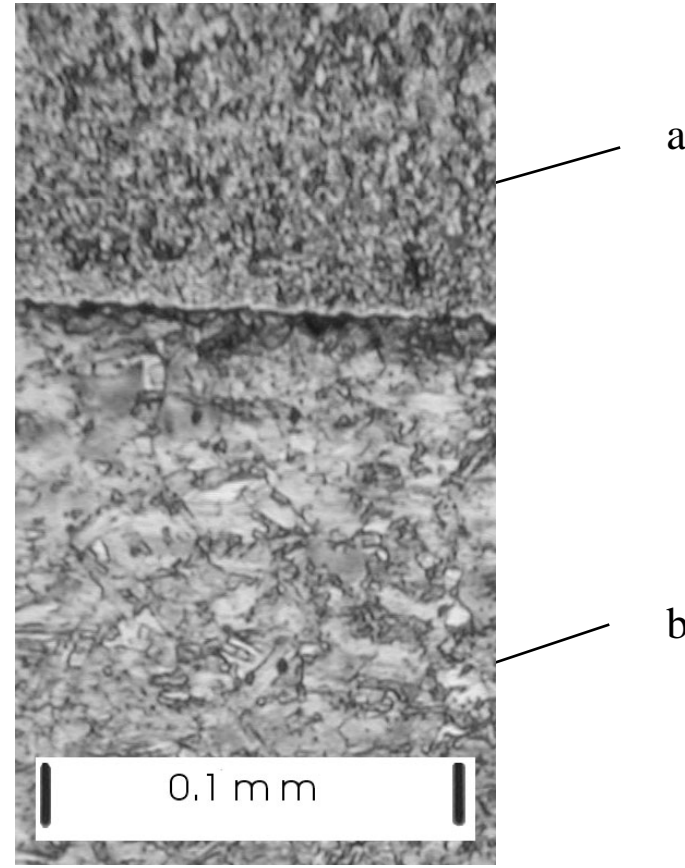

$\mathrm{a}$

Fig. 5. Micrograph of the cross-section of the nickel coating (a) deposited on a copper strip substrate (b).

Figure 5 shows the micrograph of the cross-section of a nickel coating deposited from Watt's bath on a copper strip substrate. It can be seen that the structure of the coating changes through its thickness. The structure is more finegrained at the interface.

Prestressing of the substrate by the elastic element, unlike prestressing by weights, has an effect on residual stresses. The first part of formula (1) determines residual stresses without taking into account the rigidity of the elastic element. The second part determines the effect of the rigidity of the elastic element on residual stresses. According to the 5\% criterion, the limit rigidity of the elastic element was determined as $47.3 \mathrm{~N} / \mathrm{mm}$ in our experiments. If the rigidity of the elastic element exceeds this value, we suggest in calculation to take into account the residual stress.

The data about the substrate with coating and the results of other experiments are presented in Table 1.

The experiments carried out with the present method allow to conclude that the values of residual stresses in the nickel coating deposited on a copper or brass strip and determined with the use of different elastic elements are in the same range $\left(233-261 \mathrm{~N} / \mathrm{mm}^{2}\right.$ ) and do not significantly depend on the substrate material. The maximum difference in residual stresses is up to $10 \%$, which is larger than the common maximum limit of the experimental error. When the rigidity of the elastic element was not taken into account, the difference in residual stresses in the case of the most rigid element (experiment No. 4) was 
larger than $5 \%$. Considering this result, we suggest to take the rigidity of this elastic element into account in the calculation of residual stresses. The effect of the rigidity of the elastic element on residual stresses is so small because the substrate is relatively thick and sufficiently rigid.

The obtained values of residual stresses were compared with the results found in literature. In paper $\left[{ }^{3}\right]$ a bilateral nickel coating with a final thickness of $0.1 \mathrm{~mm}$ was deposited on a low carbon steel substrate, using section dimensions $10.0 \times 0.055 \mathrm{~mm}$, from Watt's electrolyte at current density $5 \mathrm{~A} / \mathrm{dm}^{2}$, temperature $50 \pm 1{ }^{\circ} \mathrm{C}$, and $\mathrm{pH}=4.0$. Calculated (without consideration of prestressing by a spring) residual stresses were $200 \mathrm{~N} / \mathrm{mm}^{2}$ at $0.002 \mathrm{~mm}$ from the contact surface and $65 \mathrm{~N} / \mathrm{mm}^{2}$ at $0.1 \mathrm{~mm}$. These values are comparable with $207 \mathrm{~N} / \mathrm{mm}^{2}$ and $80 \mathrm{~N} / \mathrm{mm}^{2}$ obtained with the same coating thickness on a brass substrate in case when the rigidity of the elastic element was not taken into account (Fig. 4). Note that the tendencies of change in residual stress are similar throughout the coating thickness $\left[{ }^{13}\right]$.

In $\left[{ }^{17}\right]$ a nickel coating was deposited from Watt's electrolyte with the organic admixture $\mathrm{HCOOH}(2 \mathrm{~g} / \mathrm{l})$, $\mathrm{HCHO}(1.5 \mathrm{~g} / \mathrm{l})$ at current density $4 \mathrm{~A} / \mathrm{dm}^{2}$, temperature $55 \pm 0.5^{\circ} \mathrm{C}$, and $\mathrm{pH}=3.5$ on one side of the steel ribbon (section dimensions $10 \times 0.85 \mathrm{~mm}$, total length $140 \mathrm{~mm}$, length of deposition $90 \mathrm{~mm}$ ). Residual stresses were calculated from the deflection of the substrate and their maximum value for the outer layer of the coating was $240 \mathrm{~N} / \mathrm{mm}^{2}$.

The good agreement with the experimental results of other authors suggests that this method of measurement is applicable. Unlike the widely used X-ray determination of residual stresses, the distribution of stresses through the coating thickness is obtained; this data is more informative than the sign and magnitude of stresses in the outer layer of the coating. On the other hand, the stresses generated in the coating-substrate interface are very important from the point of view of adhesion of the coating to the substrate.

\section{CONCLUSIONS}

1. An experimental equipment was developed for the determination of residual stresses in galvanic coatings by the registration of the longitudinal deformation of a strip or wire substrate during deposition process.

2. The effect of the rigidity of the elastic element on residual stresses was investigated. If the rigidity of the elastic element in the case of the strip substrate exceeds the value of $47.3 \mathrm{~N} / \mathrm{mm}$, it should be taken into account in the calculation of residual stresses.

3. Residual stresses are calculated in galvanic nickel coatings deposited on a copper or brass substrate from Watt's electrolyte. Using four elastic elements and taking into account their rigidity, the values of residual stress were obtained in the range of $247 \pm 14 \mathrm{~N} / \mathrm{mm}^{2}$. 
4. The method and the experimental equipment can be used for the determination of residual tensile or compressive stresses by measuring the longitudinal deformation of a strip substrate during the process of coating removal (destructive method).

\section{ACKNOWLEDGEMENT}

The authors would like to thank engineer P. Peetsalu for the micrograph of the cross-section.

\section{REFERENCES}

1. Popereka, M. Ya. Investigation of electrocrystallization stresses in galvanic coatings. Zavodskaya Laboratoriya, 1961, 27, 1135-1138 (in Russian).

2. Dvořák, A. and Vrobel, L. A new method for the measurement of internal stress in electrodeposits. Trans. Inst. Met. Finish., 1971, 49, 153-155.

3. Wagner, E. Zur Ermittlung der Abscheidungseigenspannungen und verbleibenden Eigenspannungen in galvanisch hergestellten Nickelschichten nach der Spiralkontraktometerund Streifendehnungs-Methode. Z. Werkstofftechnik, 1975, 6, 3, 95-108.

4. Weil, R. The origins of stress in electrodeposits. Plating, 1971, 58, 50-56.

5. Perakh, M. Dilatometric determination of spontaneous macrostress in deposits II. Calculation of stress. Surface Technol., 1976, 4, 538-564.

6. Ignat'ev, V. I. and Shluger, M. A. On determination of residual stresses in galvanic coatings by the tension-compression method of a strip cathode. Zashchita Metallov, 1989, 25, 484-489 (in Russian).

7. Armyanov, S. and Sotirova, G. Diffusion-elastic phenomena in nickel and cobalt electrodeposits plated on strip cathodes. Surface Coatings Technol., 1988, 34, 441-454.

8. Shluger, M. A., Ignat'ev, V. I., Tok, L. D., and Gimel'farb, R. E. A device for determination of residual stressess in galvanic coatings. Zavodskaya Laboratoriya, 1980, 46, 764-770 (in Russian).

9. Krutskikh, V. M., Platonov, B. M., Gamburg, Yu. D., and Polukarov, Yu. M. A device for measuring of residual stresses in the electrolytic coatings by length-change method of strip cathode. Zavodskaya Laboratoriya, 1982, 48, 81-82 (in Russian).

10. Ryabchikov, A., Lille, H., and Kõo, J. A device for determination of residual stresses in galvanic coatings from the measured longitudinal deformation of a strip substrate. In Proc. 6th European Conference on Residual Stresses (Dias, A. M., Pina, J., Batista, A. C., and Diogo, E., eds.). Trans. Tech. Publications LTD, Switzerland, 2002, 263-269.

11. Wagner, E. and Speckhardt, H. Abscheidungeigenspannungen von Nickeldispersions-schichten. Metalloberfläche, 1976, 30, 175-180.

12. Kõo, J. P. On determination of residual stresses in the strengthening coatings by the method of measuring of longitudinal deformation of a cylindrical substrate. Manuscript, Estonian Agricultural University, Tartu, 1979 (in Russian).

13. Kõo, J., Lille, H., and Ryabchikov, A. On determination of residual stresses in coatings from the measured longitudinal deformation of a strip substrate. In Proc. 6th European Conference on Residual Stresses (Dias, A. M., Pina, J., Batista, A. C., and Diego, E., eds.). Trans. Tech. Publications LTD, Switzerland, 2002, 849-855.

14. Kõo, J. Layer-growing and layer removing methods for residual stress analysis: general algorithm. In Proc. 4th European Conference on Residual Stresses (Denis, S., Lebrun, J. L., Bourniquel, B., Barrel, M., and Flavenot, J. F., eds.), Cluny en Bourgogne, 1996, vol. 1, 223-232. 
15. Kir'yanov, D. Mathcad 2001. Manual for self-tution. BHV-Petersburg, Sankt-Petersburg, 2001 (in Russian).

16. Hadian, S. E. and Gabe, D. R. Residual stresses in electrodeposits of nickel and nickel-iron alloys. Surface Coatings Technol., 1999, 122, 118-135.

17. Doi, O. and Ukai, T. Residual stress measurement of multi-layered plate by curvature method. Bull JSME, 1971, 14, 1-10.

\title{
Jääkpingete määramine galvaanilistes pinnetes
}

\begin{abstract}
Alexander Ryabchikov, Harri Lille ja Jakub Kõo
On kirjeldatud mõõtesüsteemi galvaaniliste pinnete jääkpingete määramiseks ribaaluse pikideformatsiooni kaudu. Ühest otsast kinnitatud ja teise otsa kaudu raskusjõuga koormatud aluse vaba otsa siire määratakse sõltuvalt kahepoolse pinde paksusest elastse paindeelemendi deformatsioonide mõõtmisega. On uuritud jääkpingeid Wattsi elektrolüüdist vask- ja messingribale sadestatud nikkelpinnetes ja selgitatud elastse elemendi jäikuse mõju mõõtetulemustele.
\end{abstract}

